\title{
Lactose malabsorption and postgastrectomy milk intolerance, dumping, and diarrhoea
}

\author{
JOHN R. CONDON, PETER WESTERHOLM, AND NORMAN C. TANNER \\ From the Professorial Unit, Westminster Hospital, St James's Hospital, Balham, and \\ Charing Cross Hospital, London
}

In patients with deficient intestinal lactase activity there is decreased hydrolysis of ingested lactose into its constituent monosaccharides glucose and galactose, and abdominal distension, cramps, and diarrhoea may occur after the consumption of lactose-containing foods. Unhydrolysed lactose within the lumen of the small intestine has been shown to exert an osmotic effect and this can be demonstrated radiologically to result in small intestinal distension, dilution of contrast medium, and rapid transit of intestinal contents along the gut (Laws and Neale, 1966).

There are a number of reports of patients developing milk intolerance and symptoms of lactose intolerance after gastric surgery (Auricchio, Rubino, Landolt, Semenza, and Prader, 1963; Hooft, van Hauwaert, de Lacy, and Adriaenssens, 1963), and it has been suggested that intestinal lactase activity decreases following partial gastrectomy and gastrojejunosotomy of the Billroth II type (Gryboski, Thayer, Gryboski, Gabrielson, and Spiro, 1963).

It is possible that the clinical symptoms of postgastric milk intolerance, dumping, and diarrhoea might be explained by decreased intestinal lactase activity, and in order to examine such a possibility the relationship of these syndromes to lactose malabsorption was investigated in 50 patients, who, having undergone either partial gastrectomy or vagotomy with drainage, developed various combinations of milk intolerance, dumping, and diarrhoea.

\section{MATERIAL}

GROUP 1 Sixteen patients with milk intolerance, dumping, and diarrhoea.

GROUP 2 Twelve patients with milk intolerance and diarrhoea.

GROUP 3 Twelve patients with milk intolerance and dumping.

GROUP 4 Ten patients with milk intolerance only.
Milk intolerance was defined as nausea, vomiting, and abdominal pain or discomfort, occurring repeatedly, singly or in any combination following the ingestion of milk. All patients had high dietary intakes of milk and milk products preoperatively and in all cases with flat lactose tolerance curves no history was obtained of preoperative or familial milk intolerance; no patients belonged to racial groups with a known high incidence of hypolactasia.

\section{METHODS}

SUGAR TOLERANCE TESTS Oral lactose tolerance tests using $50 \mathrm{~g}$ of lactose dissolved in $500 \mathrm{ml}$ of water were performed on patients who had fasted overnight. Blood glucose levels were estimated fasting and at half-hourly intervals for two and a half hours by the glucose oxidase method using capillary blood. Similar oral tests using $25 \mathrm{~g}$ of glucose and $25 \mathrm{~g}$ of galactose were performed on patients with flat lactose tolerance curves, but not on those with normal lactose tolerance curves. After the ingestion of $50 \mathrm{~g}$ of lactose a rise in blood glucose greater than $20 \mathrm{mg} / 100 \mathrm{ml}$ above the fasting value was regarded as normal; if the rise in blood did not exceed $20 \mathrm{mg} / 100 \mathrm{ml}$ the lactose tolerance curve was described as flat.

RADIOLOGY Micropaque, $120 \mathrm{ml}$, barium sulphate suspension $100 \% 2 / \mathrm{v}$ to which $25 \mathrm{~g}$ of lactose had been added, was given orally to all patients with flat lactose tolerance curves. Films of the abdomen were taken at intervals for one and a half hours after barium lactose had been given.

The barium lactose meal in hypolactasia typically shows a grossly abnormal appearance (Fig. 1) consisting of small intestinal distension, dilution of contrast medium, and active peristalsis with rapid transit of intestinal content along the gut (Laws and Neale, 1966).

DIETARY REGIMES Before symptoms can be ascribed to lactose intolerance, they must be shown to be provoked by the administration of lactose and relieved by a lactosefree diet.

A therapeutic trial of a lactose-free diet was therefore undertaken for a period of three weeks in all patients; after this an attempt was made to precipitate symptoms by the addition of $40 \mathrm{~g}$ of lactose each day (administered as four separate $10 \mathrm{~g}$ doses with meals). 


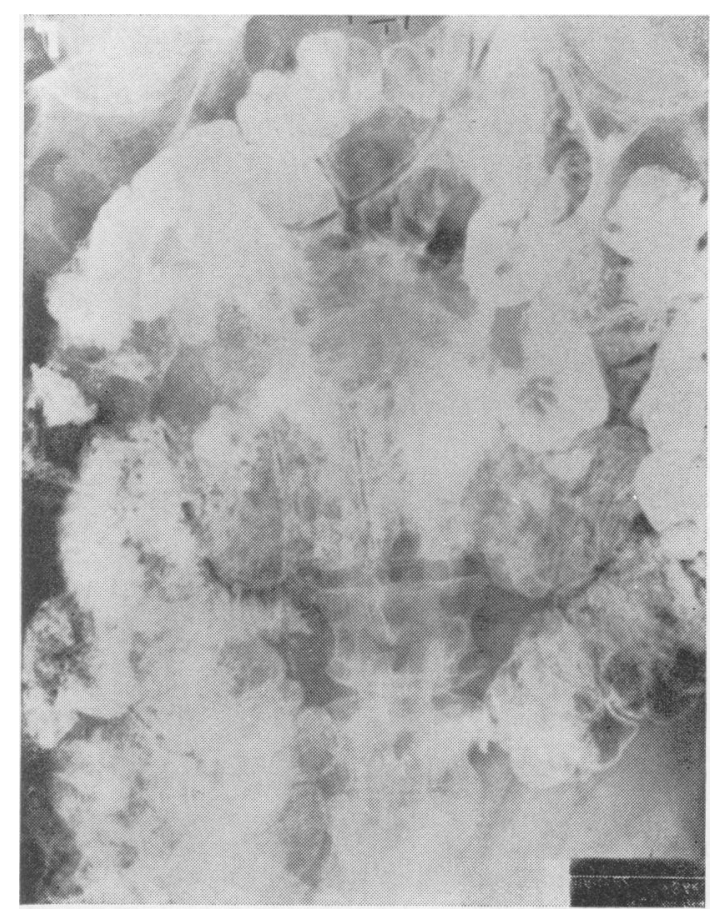

FIG. 1. Barium lactose meal demonstrating small intestinal distension and dilution of contrast medium.

\section{RESULTS}

Two patients in group 1 , five in group 2 , three in group 3, and one in group 4 had flat lactose but normal glucose-galactose tolerance curves. Each of these 11 complained of abdominal discomfort and diarrhoea during and after the lactose tolerance test but in contrast all other patients in groups 1-4 were symptomless during and for six hours after lactose ingestion.

Seven patients had barium/lactose meals which were diagnostic of lactose malabsorption. Five of these patients were in groups 1 and 2 (Table I) and two patients were in group 3. Four patients had barium lactose meals which were not diagnostic of lactose malabsorption.

The administration of a lactose-free diet completely relieved diarrhoea within a week in all seven patients with flat tolerance curves in groups 1 and 2. The addition of $40 \mathrm{~g}$ of lactose per day failed to produce abdominal discomfort and diarrhoea in the four patients with flat lactose tolerance curves in groups 3 and 4 .

In one patient faecal fat (estimated on a five-day stool collection) was $9 \cdot 2 \mathrm{~g} / 24$ hours when taking an unrestricted diet, but when a lactose-free diet with unrestricted fat was administered the value fell to $4.8 \mathrm{~g} / 24$ hours. The addition of lactose, $10 \mathrm{~g}$ qds, produced a marked increase in the frequency and fat content of stools.

\section{DISCUSSION}

The most commonly employed diagnostic procedures are the oral tolerance tests using $50 \mathrm{~g}$ of lactose administered in $500 \mathrm{ml}$, and $25 \mathrm{~g}$ of each of its corresponding monosaccharides, glucose and galactose, in the same quantity of water. The results of these tests correlate well with lactase activity (Cuatrecasas, Lockwood, and Caldwell, 1965; Haemmerli, Kistler, Ammann, Marthaler, Semenza, Auricchio, and Prader, 1965; Peternel, 1965; Sheehy and Anderson, 1965). Decreased intestinal lactase activity is practically always associated with a flat lactose, tolerance curve (maximum increase of blood glucose less

TABLE I

DETAILS OF PATIENTS WITH FLAT LACTOSE TOLERANCE TESTS IN GROUPS 1 AND 2

\begin{tabular}{|c|c|c|c|c|c|c|c|}
\hline \multirow{2}{*}{$\begin{array}{l}\text { Case } \\
\text { No. }\end{array}$} & \multirow[t]{2}{*}{ Sex } & \multirow{2}{*}{$\begin{array}{l}\text { Age } \\
(y r)\end{array}$} & \multicolumn{2}{|c|}{ Tolerance Tests ${ }^{1}(\mathrm{mg} / 100 \mathrm{ml})$} & \multirow[t]{2}{*}{ Gastric Surgery } & \multirow{2}{*}{$\begin{array}{l}\text { Postgastrectomy } \\
\text { Syndrome }\end{array}$} & \multirow{2}{*}{$\begin{array}{l}\text { Lactose Barium } \\
\text { Meal }(25 g)\end{array}$} \\
\hline & & & $\begin{array}{l}\text { Lactose } \\
(50 \mathrm{~g})\end{array}$ & $\begin{array}{l}\text { Glucose }(25 g) \\
\text { and Galactose } \\
(25 g)\end{array}$ & & & \\
\hline 1 & $\mathbf{F}$ & 42 & 5 & 60 & $\begin{array}{l}\text { Vagotomy and } \\
\text { gastroenterostomy }\end{array}$ & $\begin{array}{l}\text { Milk intolerance, } \\
\text { diarrhoea }\end{array}$ & $\begin{array}{l}\text { Diagnostic of } \\
\text { hypolactasia }\end{array}$ \\
\hline 2 & $\mathbf{M}$ & 33 & 5 & 80 & $\begin{array}{l}\text { Polya type } \\
\text { partial gastrectomy }\end{array}$ & $\begin{array}{l}\text { Milk intolerance, } \\
\text { diarrhoea }\end{array}$ & $\begin{array}{l}\text { Diagnostic of } \\
\text { hypolactasia }\end{array}$ \\
\hline 3 & $\mathbf{M}$ & 56 & 6 & 76 & $\begin{array}{l}\text { Billroth I } \\
\text { partial gastrectomy }\end{array}$ & $\begin{array}{l}\text { Milk intolerance, } \\
\text { diarrhoea, dumping }\end{array}$ & $\begin{array}{l}\text { Diagnostic of } \\
\text { hypolactasia }\end{array}$ \\
\hline 4 & $\mathbf{M}$ & 63 & 7 & 58 & $\begin{array}{l}\text { Polya type } \\
\text { partial gastrectomy }\end{array}$ & $\begin{array}{l}\text { Milk intolerance, } \\
\text { diarrhoea }\end{array}$ & $\begin{array}{l}\text { Diagnostic of } \\
\text { hypolactasia }\end{array}$ \\
\hline 5 & $\mathbf{M}$ & 61 & 10 & 55 & $\begin{array}{l}\text { Polya type } \\
\text { partial gastrectomy }\end{array}$ & $\begin{array}{l}\text { Milk intolerance, } \\
\text { diarrhoea }\end{array}$ & Negative \\
\hline 6 & $\mathbf{M}$ & 63 & 6 & 62 & $\begin{array}{l}\text { Billroth I } \\
\text { partial gastrectomy }\end{array}$ & $\begin{array}{l}\text { Milk intolerance, } \\
\text { diarrhoea, dumping }\end{array}$ & $\begin{array}{l}\text { Diagnostic of } \\
\text { hypolactasia }\end{array}$ \\
\hline 7 & $\mathbf{F}$ & 70 & 5 & 49 & $\begin{array}{l}\text { Billroth I } \\
\text { partial gastrectomy }\end{array}$ & $\begin{array}{l}\text { Milk intolerance, } \\
\text { diarrhoea }\end{array}$ & Negative \\
\hline
\end{tabular}

\footnotetext{
${ }^{1}$ Maximum rise in blood glucose above fasting value following ingestion of $50 \mathrm{~g}$ lactose and $25 \mathrm{~g}$ of glucose and $25 \mathrm{~g}$ galactose.
} 
than $20 \mathrm{mg} / 100 \mathrm{ml}$ and normal glucose and galactose tolerance curves) (Weser, Rubin, Ross, and Sleisenger, 1965; Welsh. 1966). In performing tolerance tests it is advisable that capillary blood be used for estimating blood glucose levels. Venous lactose tolerance tests will yield flat curves in approximately $25 \%$ of subjects with normal intestinal lactase activity (Newcomer and McGill, 1966). but measurements of sugar in capillary blood will eliminate most if not all such flat curves even at the expense of obtaining some normal curves in lactase-deficient subjects (McGill and Newcomer, 1967).

In all patients suffering from lactose malabsorption both tolerance tests and radiological investigations are recommended although the latter require expert interpretation and for this reason may be of less value in routine clinical practice than the tolerance tests. However, even in a patient with a flat lactose tolerance curve together with typical radiological findings at a barium-lactose meal and biopsy evidence of hypolactasia, symptoms of milk intolerance should not be ascribed to lactose intolerance until it is shown that they are provoked by the administration of lactose and relieved by a lactose-free diet.

Symptoms of milk intolerance and diarrhoea were provoked by the ingestion of $40 \mathrm{~g}$ of lactose and relieved by a lactose-free diet in all seven patients with flat lactose tolerance curves in groups 1 and 2 . Symptoms of milk intolerance in the other four patients (with flat lactose tolerance curves) in groups 3 and 4 were unrelieved by a lactose-free diet and not aggravated by the administration of $40 \mathrm{~g}$ of lactose per day although much larger doses of lactose did precipitate abdominal discomfort and diarrhoea.

Steatorrhoea was present in only one of the 11 patients with flat lactose tolerance curves; it followed total vagotomy and gastroenterostomy and responded completely to treatment with a lactose-free diet. Only one other example of steatorrhoea due to lactose intolerance and relieved by a lactose-free diet has been reported after gastric surgery and this followed vagotomy and partial gastrectomy (Bank, Barbezat, and Marks, 1966).

Although the osmotic effect of unabsorbed lactose almost certainly contributes to the rapid transit of intestinal contents along the gut, diarrhoea may also result from the production of irritant organic acids by bacterial degradation of nonhydrolysed disaccharide in the large bowel (Haemmerli et al, 1965). There is no reason why the presence of bacteria in the small bowel may not cause a similar degradation in the jejunum and ileum and interfere with fat hydrolysis and absorption resulting in steatorrhoea (Banks et al, 1966).
Lactose malabsorption should be excluded in all patients who develop diarrhoea after gastric surgery. There are, however, few reports of gastric surgery performed on patients with known hypolactasia although this must occur not infrequently since many 'normal' asymptomatic subjects have been shown to have markedly low lactase activity in biopsy specimens of the intestinal mucosa. One of two patients with hypolactasia reported by McMichael, Webb, and Dawson (1965) remained asymptomatic after partial gastrectomy, but the other developed symptoms of lactose intolerance after gastric surgery; why some previously asymptomatic patients develop symptoms of lactose intolerance after gastric surgery is, however, unknown. Presumably, although subnormal in amount, sufficient intestinal lactase is present to hydrolyse lactose into its constituent monosaccharides, glucose and galactose; after gastric surgery, however, the rate of gastric emptying may be increased and the flow of lactose into the small intestine may be too rapid for complete hydrolysis by subnormal enzyme activity.

After gastric surgery, low calcium dietary intakes were noted in most of our patients irrespective of whether they had flat lactose tolerance curves or not. Many patients had voluntarily to a greater or lesser extent excluded milk from their diets while still continuing to consume variable quantities of milkcontaining foods The amount of milk taken was, however, high preoperatively in all patients even in those with flat lactose tolerance curves. This contrasts with another reported series in which patients with low intestinal mucosal lactase activity gave a history of a markedly low intake of milk throughout their lives when compared with normal subjects (Cuatrecasas et al, 1965).

All patients with flat lactose tolerance curves in groups 1 and 2 responded to a lactose-free diet within a week. Such a diet mainly excludes chocolates, milk, and milk-containing food and is usually deficient in calcium unless large amounts of cheese are eaten. Calcium intake in the 11 patients with flat lactose tolerance tests was $790 \mathrm{mg} /$ day before gastric surgery and $260 \mathrm{mg} /$ day afterwards. This demonstrates how some subjects with lactose intolerance may adjust their eating habits so resulting in low calcium intakes, and it may be prudent, under these circumstances, to give calcium supplements.

\section{SUMMARY}

Fifty postgastric surgery patients with various combinations of milk intolerance, dumping, and diarrhoea were investigated for lactose malabsorption. 
Milk intolerance and diarrhoea were caused by lactose malabsorption in seven patients who responded to treatment with a lactose-free diet. Milk intolerance was unrelated to flat lactose tolerance tests in four patients in whom symptoms were not precipitated by the ingestion of $40 \mathrm{~g}$ of lactose a day. In five patients with flat lactose tolerance tests the incidence of dumping was unrelated to lactose ingestion and unaffected by a lactose-free diet. In one patient steatorrhoea due to lactose intolerance responded to a lactose-free diet.

It is suggested that lactose malabsorption should be excluded in all postgastric surgery patients who develop diarrhoea, and that patients with milk intolerance who exclude milk and milk-containing foods from their diet should receive dietary supplements of calcium.

We thank Dr Howells for undertaking the radiological investigations of patients.

\section{REFERENCES}

Auricchio, S., Rubino, A., Ladonlt, M., Semenza, G., and Prader, A. (1963). Isolated intestinal lactase deficiency in the adult. Lancet, 2, 324-326.
Bank, S., Barbezat, G. O., and Marks, I. N. (1966). Post-gastrectomy steatorrhoea due to intestinal lactase deficiency. Sth. Afr. med.J., 40, 597-599.

Cuatrecasas, P., Lockwood, D. H., and Caldwell, J. R. (1965). Lactose deficiency in the adult. A common occurrence. Lancet, 1, 14-18.

Gryboski, J. D., Thayer, W. R., Jr., Gryboski, W. A., Gabrielson, I. W., and Spiro, H. M. (1963). A defect in disaccharide metabolism after gastrojejunostomy. New Engl.J. Med., 268, 78-80.

Haemmerli, U. P., Kistler, H. Ammann, R., Marthaler, T., Semenza, G., Auricchio, S., and Prader, A. (1965). Acquired milk intolerance in the adult caused by lactose malabsorption due to selective deficiency of intestinal lactase activity. Amer. $J$. Med., 38, 7-30.

Hooft, C., van Hauwaert, J., de Lacey, P., and Adriaenssens, K. (1963). Malabsorption after total gastrectomy in childhood. Helv. paediat. Acta, 18, 502-517.

Laws, J. W., and Neale, G. (1966). Radiological diagnosis of disaccharidase deficiency. Lancet, 2, 139-143.

McGill, D. B., and Newcomer, A. D. (1967). Comparison of venous and capillary blood samples in lactose tolerance testing. Gastroenterology, 53, 371-374.

McMichael, H. B., Webb, J., and Dawson, A. M. (1965). Lactase deficiency in adults: a cause of functional diarrhoea. Lancet, 1, 717-720.

Newcomer, A. D., and McGill, D. B. (1966). Lactose tolerance tests in adults with normal lactase activity. Gastroenterology, $50,340-346$.

Peternel, W. W. (1965). Lactose tolerance in relation to intestinal lactase activity. Ibid., 48, 299-306.

Sheehy, T. W., and Anderson, P. R. (1965). Disaccharidase activity in normal and diseased small bowel. Lancet, 2, 1-5.

Welsh, J. D. (1966). On the lactose tolerance test. Gastroenterology, $51,445-446$.

Weser, E., Rubin, W., Ross, L., and Sleisenger, M. H. (1965). Lactase deficiency in patients with "the irritable-colon syndrome". New Engl. J. Med., 273, 1070-1075. 